\title{
Pathologies of the skin and its appendages in endocrine diseases
}

\section{Patologie skóry i jej przydatków w schorzeniach endokrynologicznych}

\author{
Hubert Arasiewicz', Martyna Zbiciak-Nylec², Ligia Brzezińska-Wcisło'
}

School of Medicine in Katowice, Medical University of Silesia in Katowice, Department of Dermatology, Poland ${ }^{2}$ Andrzej Mielęcki Silesian Independent Public Clinical Hospital in Katowice, Department of Dermatology, Poland

Przegl Dermatol 2016, 103, 143-152 DOI: 10.5|| $4 / \mathrm{dr} .2016 .59137$

KEY WORDS:

endocrine disorders, skin lesions, diagnosis.

SŁOWA KLUCZOWE:

zaburzenia endokrynologiczne, zmiany skórne, diagnoza.

\author{
ADDRESS FOR \\ CORRESPONDENCE: \\ Hubert Arasiewicz MD \\ Department of Dermatology \\ Medical University of Silesia \\ 20-24 Francuska St \\ 40-027 Katowice, Poland \\ Phone: +48 608535285 \\ E-mail: hubert.arasiewicz@ \\ gmail.com
}

\begin{abstract}
Patients suffering from endocrine disorders often present a wide profile of skin lesions. In hyperthyroidism we observe hair loss, lower leg myxedema and onycholysis or, in the case of hormone deficiency, generalized swelling of the skin, which becomes cold and pale. Primary hyperparathyroidism is revealed by pruritus, presence of chronic urticaria or deposition of amorphous calcium salts. In hypoparathyroidism, the skin is dry while the nails become very brittle. Skin lesions in diabetes include necrobiosis lipoidica, granuloma annulare, scleroderma-like diabetic edema and acanthosis nigricans. Overactive pituitary gland is often manifested as acromegaly with hypertrophy of soft tissue thickening and hypertrichosis. The skin in the early stages of hypopituitarism feels swollen, is pale yellow and oily, and finally becomes alabaster and dry. The characteristic features of Cushing syndrome are central obesity, lunar face, buffalo hump, and striae. In Addison's disease we observe hyperpigmentation. Hyperandrogenism in women leads to acne, hirsutism and virilization.
\end{abstract}

\section{STRESZCZENIE}

Zaburzeniom endokrynologicznym często towarzyszy szeroki zakres zmian skórnych. W nadczynności tarczycy obserwujemy utratę włosów, obrzęk przedgoleniowy i odwarstwienie płytki paznokciowej lub - jak w przypadku niedoboru hormonów - uogólniony obrzęk śluzowaty skóry, która staje się zimna i blada. Pierwotna nadczynność przytarczyc objawia się świądem, obecnością przewlekłej pokrzywki lub odkładaniem bezpostaciowych soli wapnia. W niedoczynności przytarczyc skóra jest sucha, natomiast paznokcie są bardzo kruche. Zmiany skórne w cukrzycy obejmują między innymi obumieranie tłuszczowate, ziarniniaka obrączkowatego, obrzęk cukrzycowy twardzinopodobny oraz rogowacenie ciemne. Nadczynność przysadki często objawia się jako akromegalia z przerostem tkanek miękkich, pogrubieniem rysów twarzy oraz nadmiernym owłosieniem. Skóra w początkowym okresie niedoczynności przysadki sprawia wrażenie obrzękniętej, jest bladożółta i tłusta, a w miarę progresji zaburzeń staje się alabastrowa i sucha. Charakterystyczne cechy zespołu Cushinga to centralna otyłość, księżycowata twarz, bawoli kark oraz rozstępy. W chorobie Addisona obserwujemy przebarwienia. Hiperandrogenizm u kobiet powoduje trądzik, hirsutyzm oraz wirylizację. 


\section{INTRODUCTION}

The endocrine system coordinates the activity of various organs via hormones which are released to the circulatory system from cells belonging to the endocrine organs. Hormones bind selectively to receptors located inside or outside the target cells. Their secretion is regulated centrally via the pituitary gland and hypothalamus. Any deviations concerning hormone excess or deficiency disturb the subtle homeostasis, resulting in systemic complications which are often life-threatening. This article aims to present the commonest endocrinopathies and related skin manifestations. It also includes a brief discussion on laboratory tests facilitating correct diagnosis [1-3].

\section{HYPERTHYROIDISM}

Hyperthyroidism is characterized by accelerated metabolism and elevated values of free thyroid hormones (thyroxine - T4 and triiodothyronine - T3) in the serum. The commonest $(60-90 \%)$ cause of thyrotoxicosis is Graves-Basedow disease. Other (less common) causes of thyrotoxicosis include isolated adenoma, toxic goiter, thyroiditis and iatrogenic excessive supplementation of thyroid hormone. Typical symptoms include tachycardia, fatigue, weight loss and tremor.

\section{Skin lesions}

The skin of patients suffering from hyperthyroidism is usually warm, moist, velvety, smooth and pink (salmon-like color). Increased temperature and dilation of the peripheral blood vessels may favor shortterm episodes of reddening of the face, upper chest and hands combined with flashes. Excessive sweating is most intense on hands and feet. The hairs on the scalp become thin, silky and glossier. Increased loss of that hair (general or concerning only the fore-

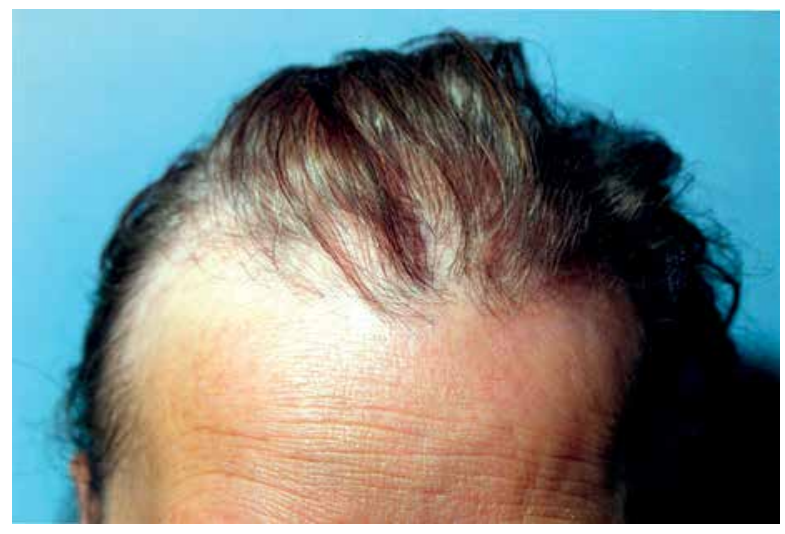

Figure I. Hyperthyroidism. Hair on the head becomes thin, silky and glossier

Rycina I. Włosy w przebiegu nadczynności tarczycy head area) affects approximately $20-40 \%$ of patients and does not correlate with the intensity of hyperthyroidism (Fig. 1). The trichoscopic test reveals a small number of telogen hairs. In rare cases alopecia areata or hair thinning in the armpits, the trunk or the pubic area as well as thinning of the eyelashes may be observed. Approximately $5 \%$ of patients develop nail lesions: the nails become shiny, delicate and brittle. Some patients also suffer from spoon nails, yellow nail syndrome, leukonychia or separation of the distal part of the nail plate from the nail bed (onycholysis). A large number of patients demonstrate diffuse discolorations around the mouth and on the trunk, which constitute an embarrassing esthetic defect. The most characteristic ones are referred to as Jellinek's sign, i.e. clear-cut brown or brown-black hyperpigmentations on the lids and around the eyes (especially intense near the inner corner of the eye). Vitiligo, which is classified in the group of autoimmune diseases, is most commonly found in patients with Graves-Basedow disease (Fig. 2). Other (less common) skin lesions in the course of hyperthyroidism include urticaria, increased dermographism, anetoderma (macular dermatrophy) (Fig. 3) and sweat gland adenomas (Fig. 4). Also lower leg myxedema occurs in about $1 \%$ of patients with Graves-Basedow disease. These skin lesions have the form of symmetrical infiltrations on the front parts of lower legs (they can also spread to the dorsal areas of the feet). This condition is nearly always combined with thyroid associated orbitopathy (TAO) [1-10].

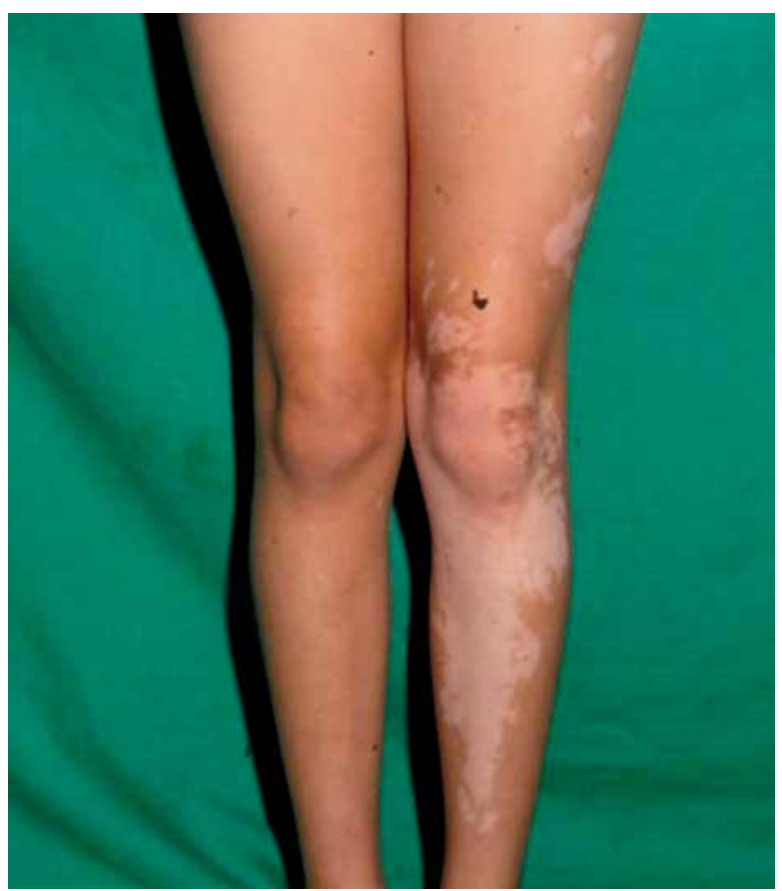

Figure 2. Vitiligo due to hyperthyroidism

Rycina 2. Bielactwo w przebiegu nadczynności tarczycy 


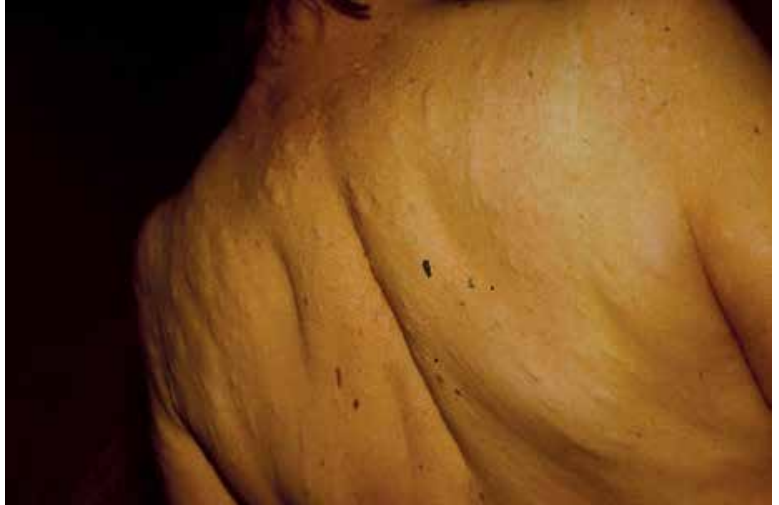

Figure 3. Anetoderma (macular dermatrophy) due to hyperthyroidism Rycina 3. Zanik plamisty skóry w przebiegu nadczynności tarczycy

\section{HYPOTHYROIDISM}

Hypothyroidism means a deficiency of thyroid hormones. Its commonest cause is iodine deficiency in the diet. Other causes include autoimmune thyroiditis (Hashimoto's disease) and iatrogenic condition after radioiodine treatment or goiter-related surgery. Rare causes of hypothyroidism are taking lithium or secondarily insufficient secretion of thyrotropin-releasing hormone (TRH). Typical symptoms include bradycardia, weight gain, fatigue, difficulties with concentration, depressive episodes, chronic constipation, intolerance of cold and slow, low-toned speech.

\section{Skin lesions}

The skin of patients suffering from hypothyroidism is usually dry, coarse and peeling. This is accompanied by keratosis pilaris, associated with itching. A characteristic skin feature is its grayish color on elbows and knees, which makes them appear "dirty". As the primary disease progresses, the skin becomes pale, cold and wax-like. Acquired palmar and plantar keratoma is also observed (Fig. 5). The

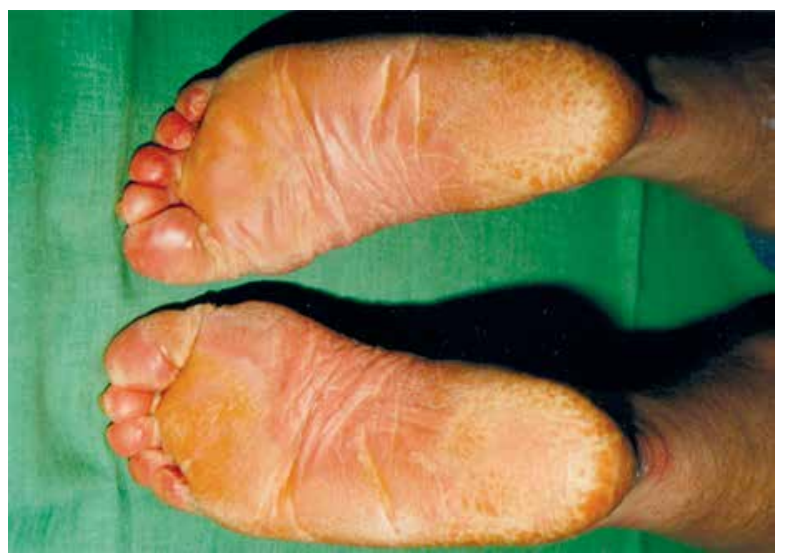

Figure 5. Acquired plantar keratoma due to hypothyroidism Rycina 5. Nabyty rogowiec stóp w przebiegu niedoczynności tarczycy

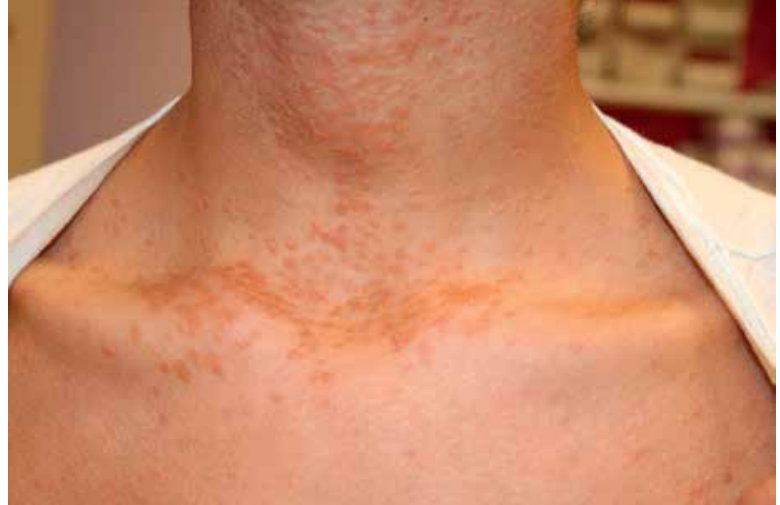

Figure 4. Sweat gland adenomas due to hypothyroidism

Rycina 4. Gruczolaki potowe w przebiegu niedoczynności tarczycy

most striking symptom of hypothyroidism is generalized skin myxedema caused by the accumulation of mucopolysaccharides. These lesions do not have a tendency to regress. They most often affect the face, causing its characteristic "mask-like" appearance due to blurred features and hindered expression. The lids become thick and swollen, while ear lobes become thick, elongated and gelatinous. The skin looks swollen and resembles dough, but touching leaves no hollows in it. Mucous membranes demonstrate increased secretion, which favors tooth decay. The tongue is thicker and enlarged, so it hinders speech and makes it indistinct. Sensation disorders in distal limbs may also occur sometimes. As the edema increases, the skin becomes coarse and thickens; this is accompanied by moderate hyperkeratosis. The hair becomes dry, coarse, brittle and dull. Some patients demonstrate an increased number of telogen hairs resulting in diffuse hair loss even in $50 \%$ of patients (Fig. 6). One can also observe Hertoghe's sign, i.e. loss of the outer third of the eyebrows (Fig. 7). Nails grow slowly, are very flat and brittle, and show longitudinal and transverse grooves [1-10].

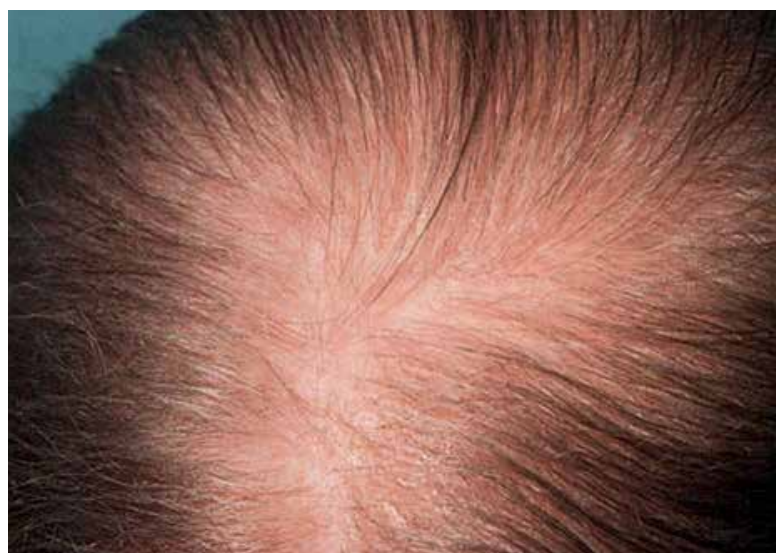

Figure 6. Diffuse hair loss due to hyperthyroidism

Rycina 6. Rozlana utrata włosów w przebiegu niedoczynności tarczycy 


\section{AUTOIMMUNE DISEASES OF THE THYROID GLAND}

Hashimoto's thyroiditis and Graves-Basedow disease belong to a group of diseases in the pathogenesis of which the main role is played by the immune system. Regardless of the thyroid gland functioning, one can observe skin lesions whose etiopathogenetic relationship with the former cannot be fully proved. Concomitance of skin lesions and autoimmune diseases of the thyroid gland is probably related to the presence of specific antibodies, even in the case of euthyroidism.

\section{Skin lesions}

The commonest concomitant skin lesions include pigmentation disorders. The most frequent discoloration is chloasma, i.e. the appearance of clear-cut, symmetrical, hyperpigmented stains on the cheeks, forehead or (less commonly) on the nape of the neck and upper lip. This is strongly related to the presence of anti-thyroid peroxidase (anti-TPO) microsomal antibodies and anti-thyroglobulin (anti-TG) antibodies, especially when chloasma develops during pregnancy or after taking oral contraceptives. Another disorder which is statistically more frequent in comparison to the healthy population is vitiligo, i.e. clear-cut skin lesions with no pigment whatsoever, usually located on the dorsa of the hands, face and neck. Alopecia areata is also related to autoimmune diseases of the thyroid gland in nearly $60 \%$ of cases. Other concomitant skin lesions include pemphigus, bullous pemphigoid, dermatitis herpetiformis, systemic lupus erythematosus, systemic sclerosis and Sjögren's syndrome [1-3, 6, 7, 9].

\section{HYPERPARATHYROIDISM}

Parathyroid glands usually form two pairs under the lower and upper poles of the thyroid gland. They secrete parathormone, which is responsible for calcium blood level regulation. Primary hyperparathyroidism caused by adenoma or parathyroid

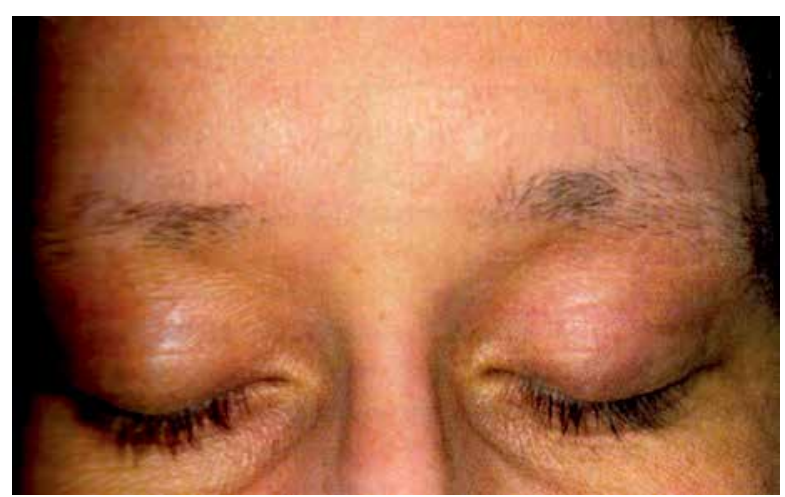

Figure 7. Hertoghe's sign due to hypothyroidism

Rycina 7. Objaw Hertoghe'a w przebiegu niedoczynności tarczycy gland hypertrophy is usually not combined with the presence of skin lesions except rare itching, dryness or calcium salt deposits. A few patients may demonstrate symptoms of chronic urticaria. Hairy skin lesions include hair breakage just above the skin surface. One can also observe generalized hair loss on the whole body.

Patients with developed secondary hyperparathyroidism in the course of chronic renal insufficiency demonstrate a range of skin lesions caused by amorphous calcium salt deposits. Skin calcifications are divided into metastatic, dystrophic and idiopathic calcinosis as well as calciphylaxis (the latter is mainly related to vessels). Skin lesions are usually hard, symmetrical, white subcutaneous papules or cracks and rhagades on digit pulps and heels which are difficult to heal $[1-3,10,11]$.

\section{HYPOPARATHYROIDISM}

Hypoparathyroidism is a serious endocrine disorder, in which insufficient parathormone secretion leads to hypocalcemia, hyperphosphatemia and hypercalciuria. Hypoparathyroidism usually results from a complication of surgery, neoplastic infiltration or an autoimmune process. Typical symptoms include paresthesias, tetany, mental disorders and painful muscle spasms.

\section{Skin lesions}

Skin in the course of hypoparathyroidism is dry, demonstrates increased sweating and tends to develop discolorations. Moreover, the patients are prone to eczematous and urticarial lesions. The hairs, like in hyperthyroidism, break just above the skin surface and have a tendency for generalized falling out. Early graying is also observed (Fig. 8). Nail plate lesions include increased breaking and brittleness (Fig. 9), a tendency to split, onycholysis, leuconychia and transverse grooves (Fig. 10) [1-3, 10, 11].

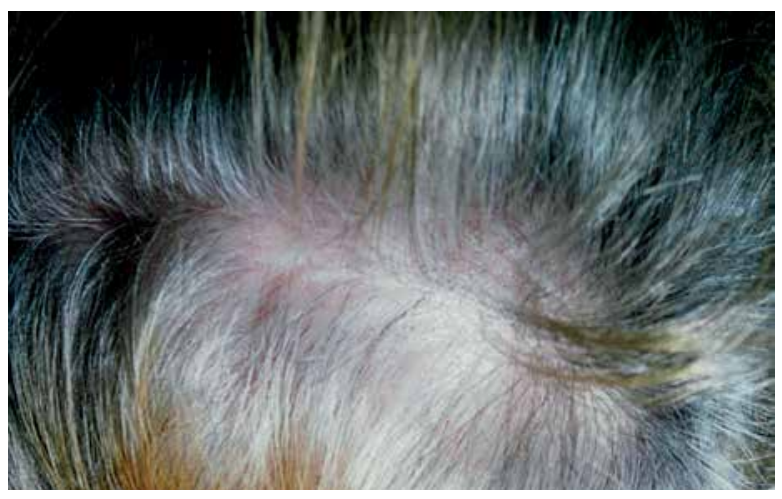

Figure 8. Early graying due to hypoparathyroidism

Rycina 8. Wczesne siwienie w przebiegu niedoczynności przytarczyc 


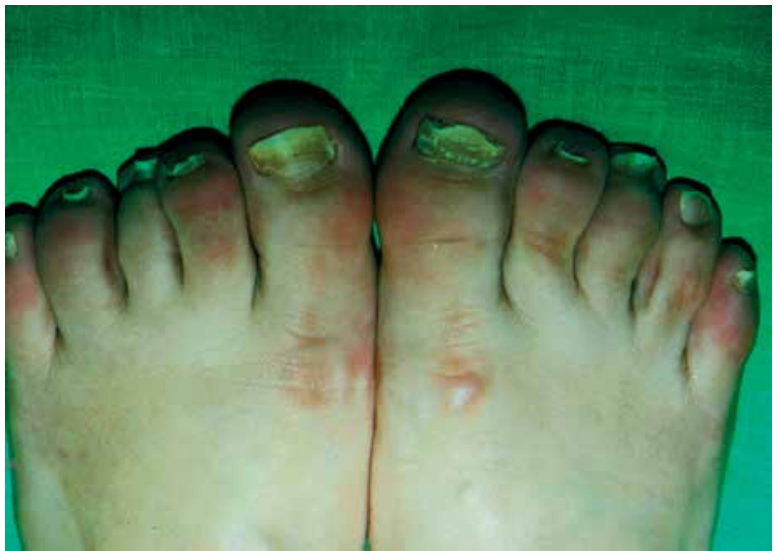

Figure 9. Nail plate lesions due to hypoparathyroidism

Rycina 9. Zmiany płytek paznokciowych w przebiegu niedoczynności przytarczyc

\section{DIABETES}

Diabetes is a disease of civilization which encompasses a range of metabolic disorders. It is characterized by hyperglycemia stemming from a production or functioning defect of insulin secreted by pancreatic beta cells. Chronic hyperglycemia directly contributes to the functioning disturbances or even insufficiency of various organs including eyes, kidneys, nerves, heart and blood vessels. The most characteristic symptoms include polyuria (increased urine output), polydipsia (increased thirst) and polyphagia (increased hunger).

\section{Skin lesions}

Skin lesions are present in 30-70\% of patients with diagnosed diabetes. Certain diseases including necro-

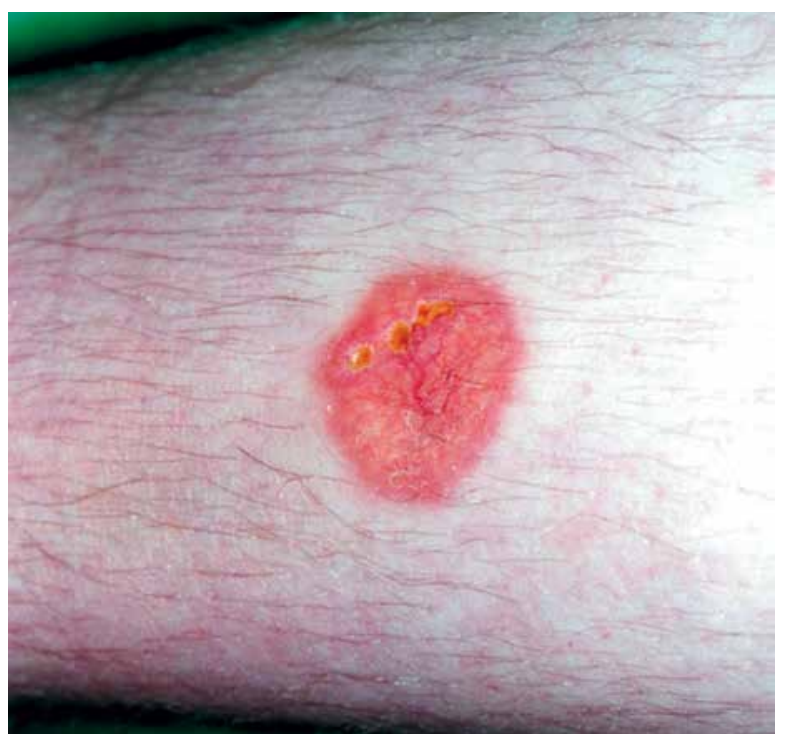

Figure II. Necrobiosis lipoidica due to diabetes

Rycina II. Obumieranie tłuszczowate w przebiegu cukrzycy

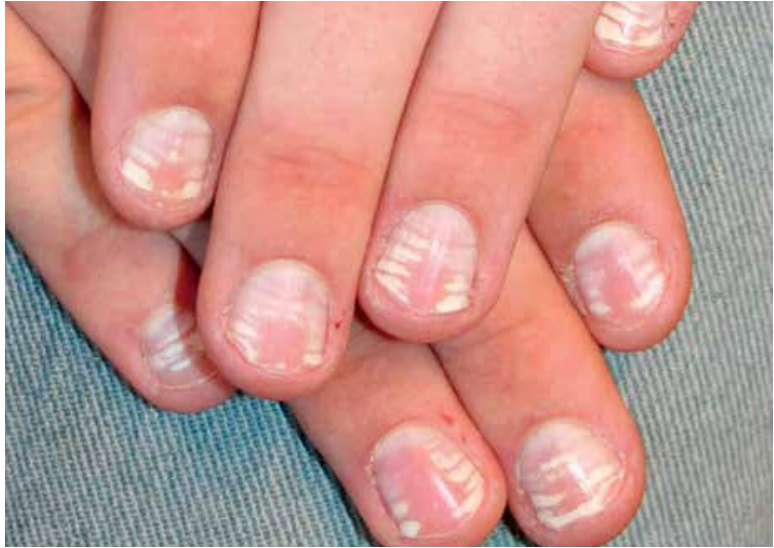

Figure 10. Leuconychia and transverse grooves of nail due to hypoparathyroidism

Rycina 10. Bielactwo paznokci oraz poprzeczne bruzdowanie w przebiegu niedoczynności przytarczyc

biosis lipoidica are closely related to diabetes and develop in approximately $0.3 \%$ of patients. The lesions are most often located on the extensor and lateral parts of lower legs; they form infiltrative and atrophic foci which tend to develop necrosis and ulceration (Figs. 11, 12). They need to be distinguished from granuloma annulare, another disease which is often concomitant with diabetes. The skin lesions are mainly located on the dorsal part of the limbs and on the nape of the neck; they are annular, slightly prominent foci without a tendency for ulceration (Figs. 13, 14). Microangiopathies and polyneuropathies favor mild lesions in the form of rubeosis diabeticorum and serious deep mixed ulcerations as a consequence of socalled diabetic foot. Acanthosis nigricans related to insulin resistance is equally frequent in type 1 and type 2 diabetes. It is characterized by the presence of

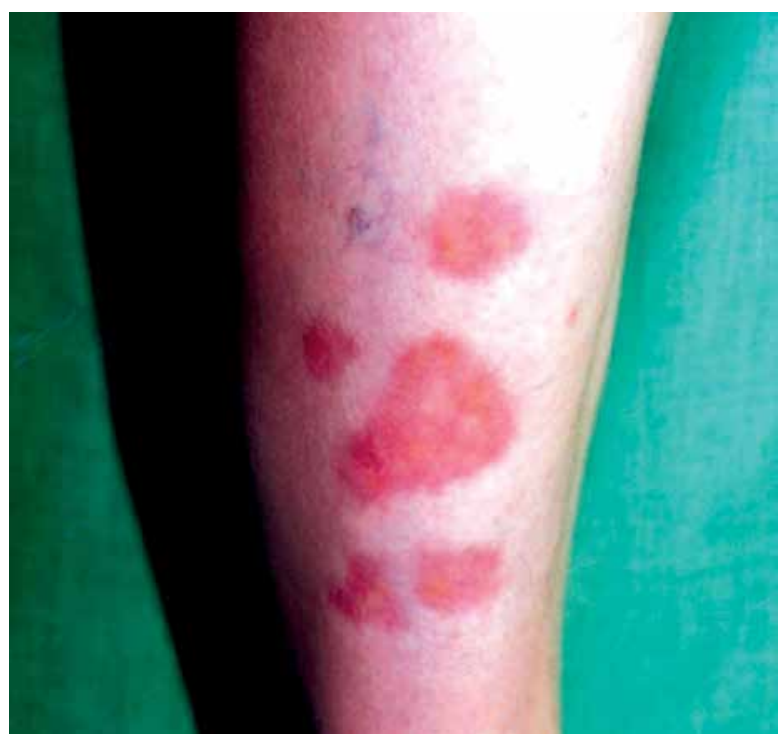

Figure I2. Necrobiosis lipoidica due to diabetes

Rycina 12. Obumieranie tłuszczowate w przebiegu cukrzycy 


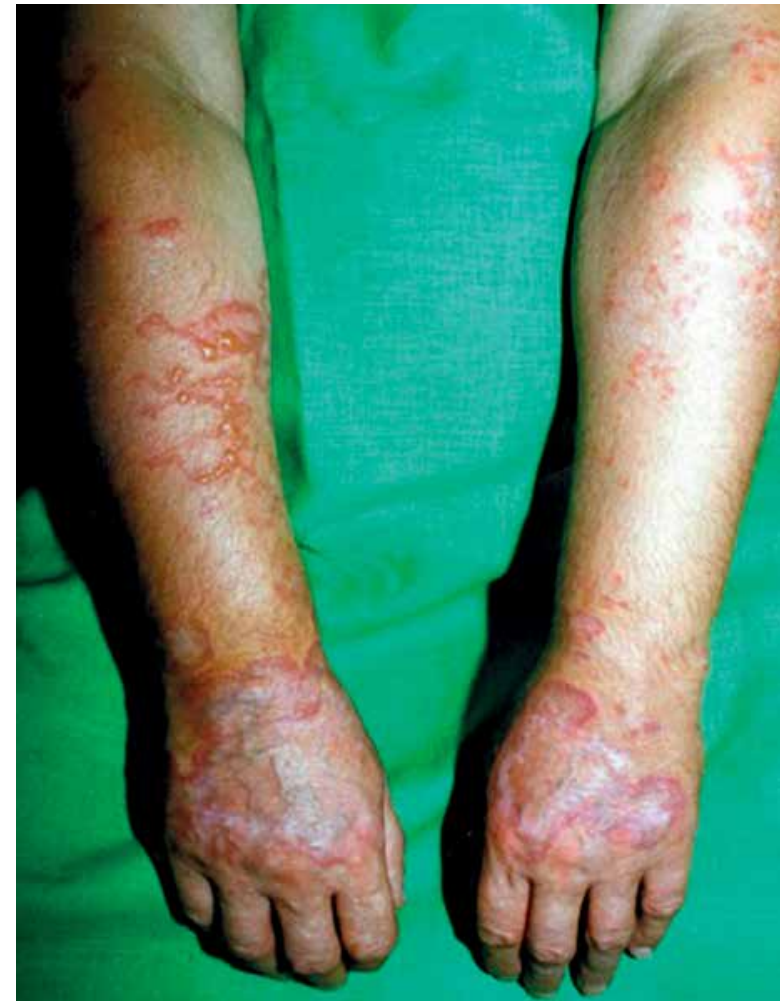

Figure 13. Granuloma annulare due to diabetes

Rycina 13. Ziarniniak obrączkowaty w przebiegu cukrzycy

thickened, hyperkeratotic, wart-developing, excessively pigmented skin, mainly in the area of the armpits and the neck as well as (less commonly) around the mammary areola, in the cubital fossa, umbilicus and crotch (Fig. 15). Patients often report generalized skin itching of various intensity. Due to concomitant lipid metabolism disturbances, one can observe xanthomas, which constitute an esthetic defect. The oral cavity of a patient with uncontrolled diabetes is characterized by the presence of lip sores, decay-affect-

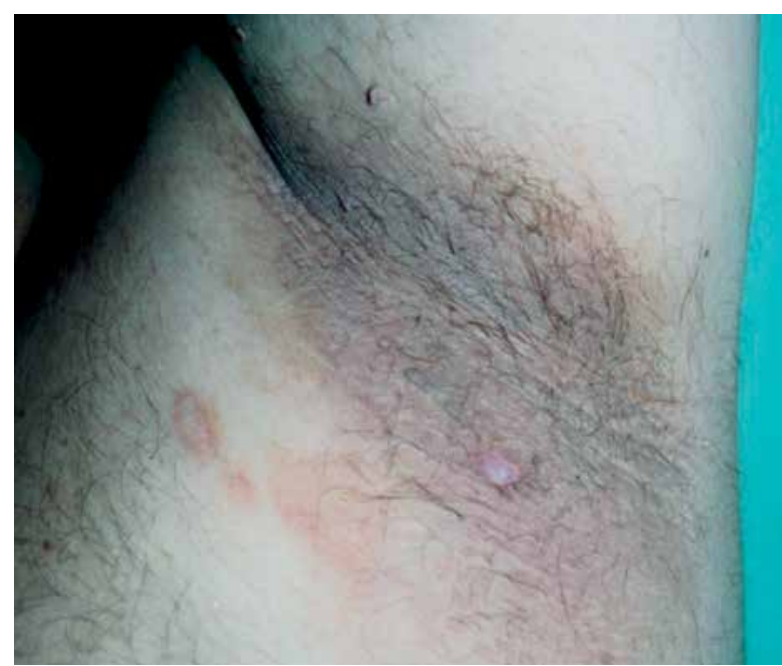

Figure 15. Acanthosis nigricans due to diabetes

Rycina 15. Rogowacenie ciemne w przebiegu cukrzycy

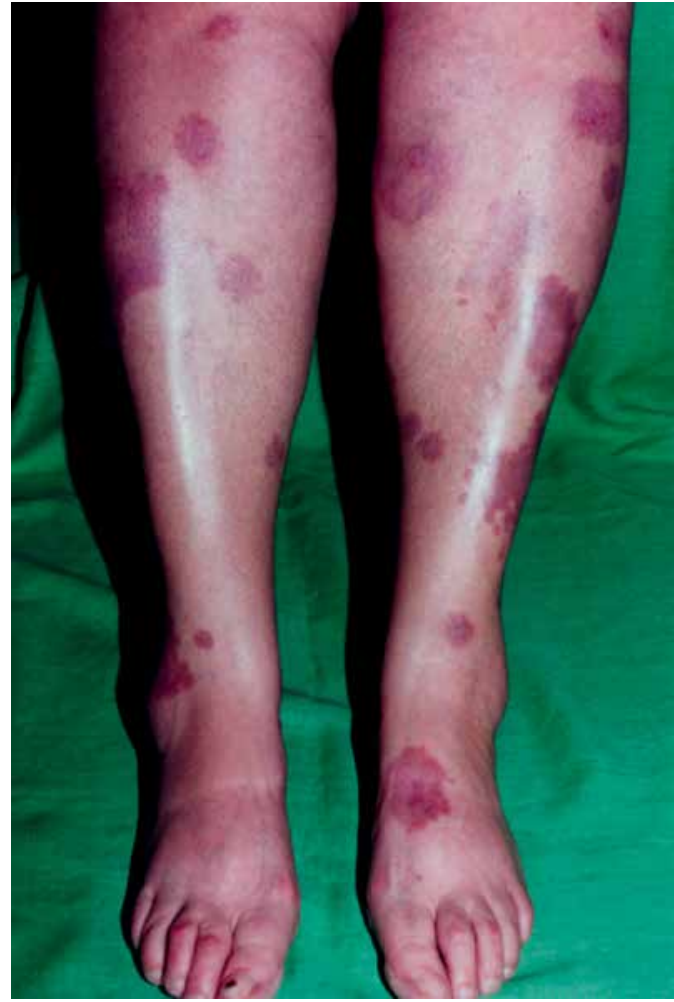

Figure 14. Granuloma annulare due to diabetes

Rycina 14. Ziarniniak obrączkowaty w przebiegu cukrzycy

ed teeth and a big, bluish-red tongue with teeth imprints on the sides. Scleroderma-like diabetic edema means lesions which resemble scleroderma and are located on the nape of the neck and the upper part of the trunk; they are complications of long-term, insulin-dependent, uncontrolled diabetes (Fig. 16). One third of diabetic patients demonstrate hand skin hardening. Moreover, vitiligo is statistically more frequent in comparison to the healthy population. Other skin lesions observed in diabetes include bullae on the fingers and dorsal hand areas. One must also remember that drugs taken by the patient may cause urticaria, photoallergic and phototoxic reactions or subcutaneous tissue atrophy in the areas of permanent insulin injections.

Scalp lesions include diffuse hair loss, which is more intense on the top of the head (Fig. 17). It always demonstrates a telogenic mechanism and precedes the diabetes diagnosis by many years. The percentage of telogen hairs does not depend on the period of diabetes or the period of hair loss. Head hairs of diabetic patients treated with insulin are in better condition and thus there is a higher percentage of anagen hairs. Patients with uncontrolled diabetes usually experience hair loss in the third and fourth decades of life; it is accompanied by more intense seborrhea. In general in diabetes an increased tendency for bacterial, mycotic and viral infections, sebum secretion disorders as well as excessive hair 


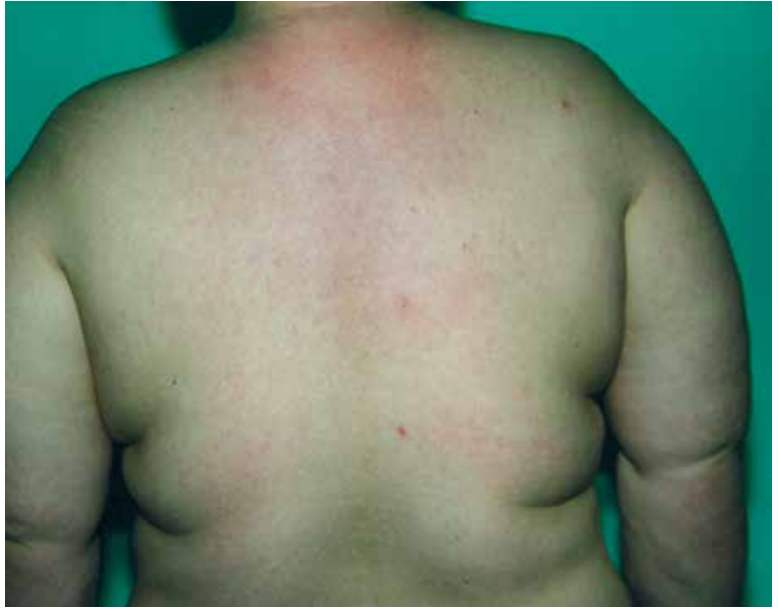

Figure 16. Scleroderma-like diabetic edema

Rycina 16. Obrzęk twardzinopodobny w przebiegu cukrzycy

growth in the area of the shoulder blades and the umbilicus may be observed [1-3, 10, 12-15].

\section{HYPERPITUITARISM}

The pituitary gland located in the sella turcica is an endocrine organ strictly controlled by the hypothalamus. Regarding anatomy, the pituitary gland is divided into an anterior, middle and posterior part, which does not produce anything, but stores oxytocin and vasopressin produced by hypothalamus. Symptoms related to hyperpituitarism are usually caused by excessive selective secretion of growth hormone $(\mathrm{GH})$ and an elevated level of insulin-like growth factor 1 (IGF-1). Excessive activation of the IGF-1 receptor, located in the majority of skin cells, with special regard to the basal and prickle layers, is the basis for the observed skin lesions. Somatomedin receptors are also found in hair follicles, sebaceous glands, sweat glands, keratinocytes, fibroblasts, adipocytes, Schwann cells and skeletal muscle cells. Depending on time of appearance of symptoms, one can observe gigantism in children or acromegaly in adults. Its typical non-cutaneous symptoms include stimulated glycogenolysis, lipolysis and increased insulin secretion. Other frequently occurring conditions are sight disorders, mesiocclusion, menstruation disturbances, joint pains and sleep apnea.

\section{Skin lesions}

One observes so-called spongy edema of hand and sole skin with a tendency for skin hardening and thickening caused by generalized hypertrophy of subcutaneous fatty tissue and by the presence of glycosaminoglycans, including dermatan sulfate and chondroitin with stronger adsorption properties. The patient's facial features become thicker, the lower lip

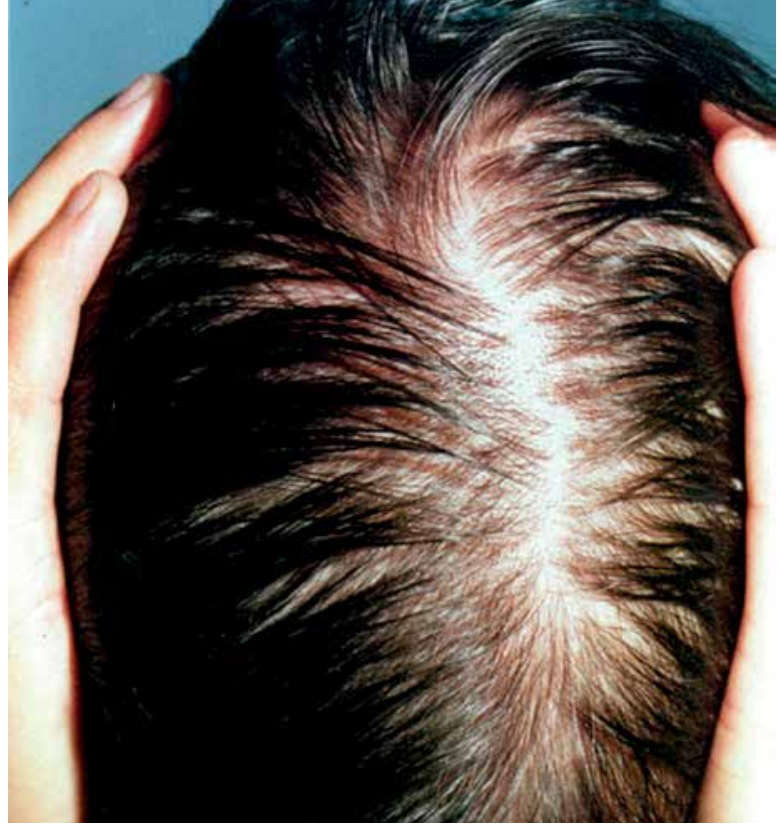

Figure 17. Diffuse hair loss due to diabetes

Rycina 17. Rozlana utrata włosów w przebiegu cukrzycy

and the nose enlarge, and the eyelids develop edema. The skin becomes coarse and demonstrates deep wrinkles (a "basset hound look").

The tongue, like in hypothyroidism, enlarges significantly and the voice becomes lower. The scalp shows a defect in the form of deep grooves resembling brain convolutions - this is known as cutis vertis gyrata. Increased hair growth is found, especially on upper and lower limbs. The hairs are thick and tend to become greasy quickly due to increased seborrhea. Straight hairs become curly and pale hairs darken; early graying is also observed. The skin becomes greasy and seborrheic with a tendency for discolorations, which are usually located on the hands, along scars and on mucous membranes as well as in the genital area. Excessive stimulation of fibroblasts and keratinocytes causes mild acanthosis nigricans in approximately $10 \%$ of patients. Acne inversa is found more frequently, and a truly onerous symptom is increased sweating. A greater number of fibromas, neurofibromas and seborrheic warts is also described. The patients' nails become thick, hard and brittle, with a tendency for ingrowing. They grow fast, their shape may resemble that of a watch glass, and they may show longitudinal stripes or be concave $[1-3,10,16-18]$.

\section{HYPOPITUITARISM}

Insufficient hormone production by the anterior lobe of the pituitary gland is usually generalized. The commonest causes of pituitary gland functioning disorders include pituitary gland tumors, neoplastic in- 
filtrations, vascular disorders and post-radiotherapy conditions. Related symptoms stem from the development of secondary disorders of subordinate endocrine glands, except the lack of discolorations in the course of adrenocorticotropic hormone (ACTH) deficiency, which causes hypoadrenocorticism. Prolactin, devoid of feedback inhibition, is excessively secreted, causing galactorrhea and intensified acne lesions.

\section{Skin lesions}

In the initial period the skin seems to be swollen; it is pale yellow and greasy. As the disorders progress, the skin becomes alabaster, dry and less elastic, and it thickens, wrinkles and intensively peels. Patients with a tendency for urticaria demonstrate significant dermographism. The hairs show no pathological features, but there is a lack of hair in the armpits and in the genital area as well as a lack of eyebrows and eyelashes. Nail plates may show longitudinal grooves and might sometimes separate from the nail bed $[1-3,10,16]$.

\section{DISEASES OF ADRENAL GLANDS}

The adrenal glands, located on the upper poles of the kidneys, consist of the cortex and medulla. The cortex produces glucocorticosteroids (mainly cortisol), mineral corticosteroids (mainly aldosterone) and androgens (mainly dehydroepiandrosterone and androstenedione). The medulla is built of chromaffin cells which produce catecholamines (mainly adrenaline and noradrenaline). Syndromes caused by hormone deficiencies concern the lack of adrenal cortex hormones. Hypoadrenalism may be either primary (as a result of adrenal cortex damage, like in Addison's disease) or secondary (stemming from disorders concerning the pituitary gland and the hypothalamus). Hyperadrenalism produces clear clinical signs: hypersecretion of androgens causes adrenal virilism, of glucocorticosteroids causes Cushing's syndrome, and of aldosterone causes hyperaldosteronism. Hyperadrenalism may be caused by congenital or acquired hypertrophy or the presence of adenomas or carcinomas.

\section{HYPOADRENALISM - ADDISON'S DISEASE}

In the past, one of the commonest reasons for presenting the symptoms of adrenal cortex insufficiency was the destruction of adrenal glands in the course of tuberculosis. Currently, the main causes are autoimmune processes. The most typical symptoms include increasing weakness, a tendency for fainting caused by orthostatic hypotonia or hypoglycemia, decreased muscle power, weight loss, diarrhea, mood depres- sion, hypotension, hypoglycemia, menstruation disturbances, hypercalcemia and hyperkalemia.

\section{Skin lesions}

The most typical skin lesions are hyperpigmentations caused by excessive melamine storage stemming from the excessive activity of adrenocorticotropin. They are generalized and their expression is strongest in the areas exposed to sunlight and irritated areas such as elbows, palmar flexion creases, areolas of the mammas and scars. Dark color is also observed on mucous membranes and lips. Approximately $10-20 \%$ of patients with hypoadrenalism caused by autoimmune mechanisms develop vitiligo. Moreover, the skin is dry and shows increased sweating. Young women demonstrate intensified keratosis pilaris, hair darkening and thinning out, especially in the armpits and in the pubic mound [1-3, 10, 19-22].

\section{CUSHING'S SYNDROME}

It is characterized by a set of clinical signs stemming from a long-term elevated serum level of cortisol. ACTH-dependent hyperadrenalism is caused by excessive ACTH secretion by the anterior lobe of the pituitary gland (Cushing's disease) or by non-pituitary tumors including small-cell lung carcinoma. ACTH-independent hyperadrenalism is caused by exogenous intake of corticosteroids or adrenal carcinoma or adenoma. Typical non-cutaneous symptoms include weight increase with so-called Cushingoid obesity, menstruation disturbances, emotional disorders, hypertension, diabetes and decreased muscle power.

\section{Skin lesions}

The skin in the course of Cushing's syndrome is thin, dry and atrophic, with clearly visible vessel dilation (telangiectasias). It has a tendency to be easily injured, and the lesions are mainly located on the extensor parts of the limbs. Injuries do not heal properly, and the skin itself is more prone to dermatophyte infections. One can observe intensified acne lesions, especially on the trunk. The patient's appearance changes in a characteristic way: the face becomes round (moon-like face) and shows clear symptoms of hyperemia, while the body develops central obesity with fat cushions in supraclavicular fossae and the so-called buffalo hump. Distal limb parts usually remain thin. One can observe wide, purple red striae on the skin of the belly, thighs and buttocks (Fig. 18). Excessive pigmentation in the form of scattered discolorations appears in areas exposed to sunlight and regular mechanical irritation (shoulders, elbows, 
knees), as well as on the mucous membranes of the oral cavity (usually along the line of occlusion). Hypertrichosis is also observed (except the scalp), while people with a tendency for alopecia demonstrate hair thinning. Women show excessive male-pattern hair growth (face, chest, belly, vulva) [1-3, 10, 23-25].

\section{DISORDERS RELATED TO THE EXCESS OF ANDROGENS}

Symptoms of androgen hypersecretion concern mainly women, for whom they constitute not only clinical disorders, but also serious psychological and esthetic problems. The commonest cause of hyperandrogenism and at the same time the most frequent hormonal disorder in women of reproductive age is polycystic ovary syndrome (PCOS). The syndrome often affects various systems and leads to many health-related consequences. Typical non-dermal symptoms include insulin resistance, rare and irregular menstruation cycles, infertility and central obesity.

\section{Skin lesions}

Typical lesions of the skin and its appendages include hirsutism with a tendency for male pattern, as well as male-pattern (androgenic) hair loss. A serious challenge is also intensified acne which does not respond to conventional treatment. Patients with PCOS equally often develop mild acanthosis nigricans $[1,10,26-28]$.

\section{DIAGNOSIS OF ENDOCRINE DISORDERS}

The above-mentioned skin lesions are a valuable guideline for possible concomitance of endocrine disorders. It is justified to provide adequate indications so that the patient can be referred to a correct outpatient clinic; this is achieved by performing basic endocrine diagnostic tests. Thyroid gland disorders require not only palpable examination of the gland, but also determination of the level of thyroid-stimulating hormone (TSH), free-thyroxine fraction (fT4) and triiodothyronine (fT3). In doubtful cases, if skin lesions are still suspected to have a thyroid-related background despite euthyroidism, one should perform an assay of anti-TPO antibodies. The diagnostics of parathyroid gland functioning disorders begins with determining characteristic symptoms from the tetany group and deviations in results of laboratory tests, such as hypocalcemia, hyperphosphatemia and a low or impossible-to-determine serum level of parathormone (PTH). The adrenal gland disorders present characteristic clinical features, but they also often require complicated hormone tests. For Cushing's syndrome, a test of choice with signif-

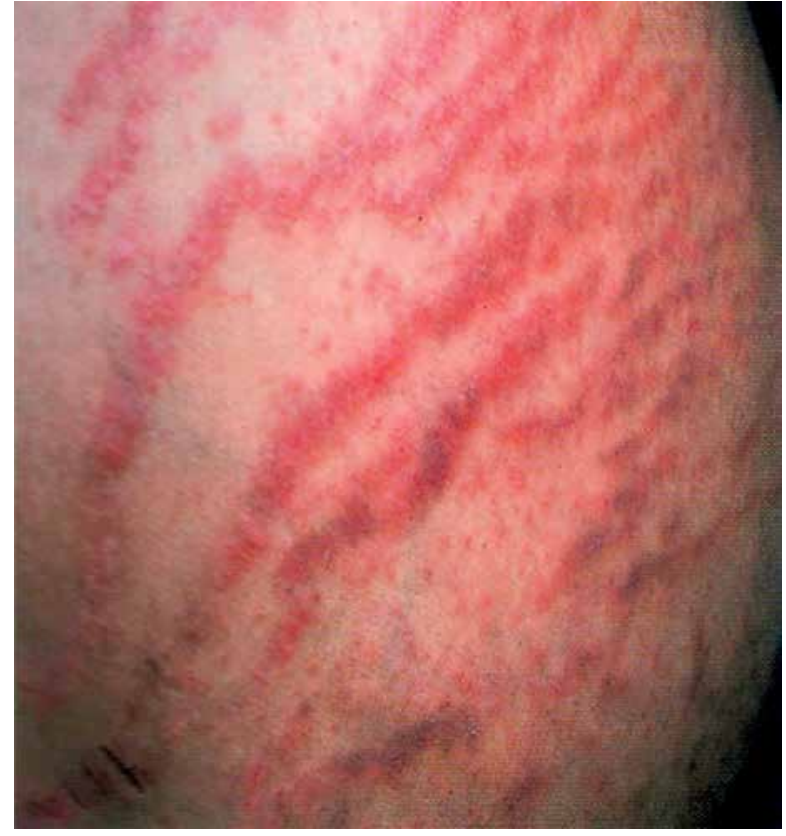

Figure 18. Striae in Cushing's syndrome

Rycina 18. Rozstępy w przebiegu zespołu Cushinga

icant specificity is 24-hour urine level of free cortisol. Addison's disease is confirmed by determining the level of cortisol and ACTH in the serum; if they are lowered, the diagnostics must also include the ACTH stimulation test. Hyperpituitarism, which usually manifests as full acromegaly, requires the determination of elevated growth hormone (GH) and IGF-1 levels. Due to daily concentration fluctuations, a secretion inhibition test is conducted after the oral glucose tolerance test (OGTT). Disorders stemming from hypopituitarism are generalized and affect every subordinate to the pituitary gland organ. Beside the above-mentioned symptoms, the diagnosis of polycystic ovary syndrome includes high insulin and testosterone levels as well as a luteinizing hormone/ follicle-stimulating hormone (LF/FSH) ratio higher than 2 . The diagnosis of diabetes, beside the characteristic symptoms of that disease, requires a glucose concentration exceeding $200 \mathrm{mg} / \mathrm{dl}$ at any time of the day, a fasting glucose level measured twice exceeding $126 \mathrm{mg} / \mathrm{dl}$, and/or a glucose concentration exceeding $200 \mathrm{mg} / \mathrm{dl}$ in the second hour of the oral glucose tolerance test [1-3].

\section{CONCLUSIONS}

The wide range of dermatoses described above may be caused by concomitant endocrine diseases. Dermatologists should be aware of the need of careful and detailed differential diagnosis. A quick and correct diagnosis using simple screening tests allows one to treat the cause and not only the symptoms of 
the disease. This may reduce the possibility of dangerous systemic complications.

\section{Conflict of interest}

The authors declare no conflict of interest.

\section{References}

1. Walter K.H., Krause W.K.: Cutaneous manifestations of endocrine diseases. Springer, Berlin Heidelberg, 2009.

2. Jabbour S.: Cutaneous manifestations of endocrine disorders. Am J Clin Dermatol 2003, 4, 315-331.

3. Jabbour S.: Skin manifestations of hormone-secreting tumors. Dermatol Ther 2010, 23, 5643-5650.

4. Daven N., Doshi M.D., Marianna L., Blyumin M.D., Alexa B., Kimball M.D.: Cutaneous manifestations of thyroid disease. Clin Dermatol 2008, 26, 283-287.

5. Kenneth D., Burman M.D., Lynn McKinley-Grant M.D.: Dermatologic aspects of thyroid disease. Clin Dermatol 2006, 24, 247-255.

6. Tomer Y., Huber A.: The etiology of autoimmune thyroid disease: a story of genes and environment. J Autoimmun 2009, 32, 321-339.

7. Parish N.M., Cooke A.: Mechanisms of autoimmune thyroid disease. Drug Discov Today 2004, 1, 337-344.

8. Artantas S., Gül Ü., Kılıç A., Güler S.: Skin findings in thyroid diseases. Eur J Intern Med 2009, 20, 158-161.

9. Julia A.J., Leonhardt J.M., Heymann W.R.: Autoimmune thyroid diseases: etiology, pathogenesis, and dermatologic manifestations. J Am Acad Dermatol 2003, 48, 641-662.

10. Brzezińska-Wcisło L.: Choroby włosów i skóry owłosionej. Termedia, Wydawnictwa Medyczne, Poznań, 2015.

11. Ghada El-Hajj Fuleihan G., Rubeiz N.: Dermatologic manifestations of parathyroid-related disorders. Clin Dermatol 2006, 24, 281-288.

12. Oumeish O.Y.: Skin disorders in patients with diabetes. Clin Dermatol 2008, 26, 235-242.

Received: $5 \times 2015$

Accepted: 7 III 2016
13. Romano G., Moretti G., Di Benedetto A., Giofre C., Di Cesare E., Russo G. i inni: Skin lesions in diabetes mellitus: prevalence and clinical correlations. Diabetes Res Clin Pr $1998,39,101-106$.

14. Ahmed I., Goldstein B.: Diabetes mellitus. Clin Dermatol 2006, 24, 237-246.

15. Morgan A.J., Schwartz R.A.: Diabetic dermopathy: a subtle sign with grave implications. J Am Acad Dermatol 2008, $58,447-451$

16. Davidovici B.B., Orion E., Wolf R.: Cutaneous manifestations of pituitary gland diseases. Clin Dermatol 2008, 26, 288-295.

17. Chanson P., Salenave S.: Acromegaly. Orphanet J Rare Dis $2008,3,17$.

18. Hossain B., Drake W.M.: Acromegaly. Medicine 2013, 41, 512-515.

19. Løvås K., Husebye E.S.: Addison's disease. Lancet 2005, 365, 2058-2061.

20. Brooke A.M., Monson J.P.: Addison's disease. Medicine 2013, 37, 416-419.

21. Nieman L.K., Chanco Turner M.L.: Addison's disease. Clin Dermatol 2006, 24, 276-280.

22. Napier C., Pearce S.H.S.: Autoimmune Addison's disease. Medicine 2012, 41, e626-e635.

23. Daniel E., Newell-Price J.: Cushing's syndrome. Medicine 2013, 41, 508-511.

24. Newell-Price J., Bertagna X., Grossman A.B., Nieman L.K.: Cushing's syndrome. Lancet 2006, 367, 1605-1617.

25. Shibli-Rahhal A., Beek M., Schlechte J.A.: Cushing's syndrome. Clin Dermatol 2006, 24, 260-265.

26. Arlt W., Allolio B.: Adrenal insufficiency. Lancet 2003, 361, 1881-1893.

27. Housman E., Reynolds R.V.: Polycystic ovary syndrome: a review for dermatologists. Part I. Diagnosis and manifestations. J Am Acad Dermatol 2014, 71, 847e1-847e10.

28. Goodarzi M.O., Carmina E., Azziz R.: DHEA, DHEAS and PCOS. J Steroid Biochem 2015, 145, 213-225. 